\title{
The density and diversity of plant-parasitic nematodes associated with maize rhizosphere in Malakaji Highland, South Sulawesi, Indonesia
}

\author{
HISHAR MIRSAM", AMRAN MUIS, NURNINA NONCI \\ Indonesian Cereals Research Institute, Indonesian Center for Food Crops Research and Development, Indonesian Agency for Agricultural Research and \\ Development, Ministry of Agriculture. Jl. Dr. Ratulangi 274, Maros 90514, South Sulawesi, Indonesia. Tel.: +62-11-371529, 371016, Fax.: +62-11-371961, \\ vemail: hisharmirsam@yahoo.co.id
}

Manuscript received: 19 March 2020. Revision accepted: 18 May 2020.

\begin{abstract}
Mirsam H, Muis A, Nonci N. 2020. The density and diversity of plant-parasitic nematodes associated with maize rhizosphere in Malakaji Highland, South Sulawesi, Indonesia. Biodiversitas 21: 2654-2661. Plant-parasitic nematodes (PPNs) are one of the important pathogens, especially in tropical countries, including Indonesia. Nematodes can cause high yield losses and economic damage if not managed properly. This study aims to analyze PPN density in the vegetative phase of maize in the Malakaji Highland Gowa Regency, South Sulawesi. The sampling method was a diagonal sampling technique, done by taking samples at points along a diagonal line, which were the middle and fourth corners of the maize crop. Nematode extraction was done by the modified Baerman method. The density of parasitic nematode communities counted was absolute community density, relative community density, absolute frequency, relative frequency, frequency of all nematodes, and dominance values. Nematode identification was based on morphological characters. The highest PPNs density was found in two weeks old of maize planted area where the absolute community density reaching 618 and the dominance value of $61.80 \%$. Age of maize plants is negatively correlated with PPNs community with a regression coefficient of (3.85). So that it can be assumed that the older the age of maize plants, the lower the amount of PPNs. Five genera of plant-parasitic nematodes associated with the rhizosphere of maize plants were found, namely Helicotylenchus, Pratylenchus, Haplolaimus, Longidorus, and Xiphinema. In addition to parasitic nematodes, non-parasitic nematodes were also identified as having no stylet, namely Campydoroides, Mononchus, and Rhabditis.
\end{abstract}

Keywords: Maize plant, nematode, soil-borne pathogen

\section{INTRODUCTION}

Maize is an agricultural commodity that is a top priority for improving food security in Indonesia. South Sulawesi is one of the largest maize-producing regions in Indonesia, with an average harvest area of 295,115 ha and a production of 1,528,414 tons (CBS South Sulawesi 2018). The effort to develop maize in South Sulawesi still faces several constraints, both in cultivation techniques and in the incidence of pests. Previous studies have reported that maize cultivation is often effected by plant diseases, including those caused by soil-borne fungi that can reduce production, such as Rhizoctonia solani and Fusarium spp. (Suriani and Muis 2016; Soenartiningsih et al. 2015). The intensity of the pathogen incidence can be severe if it is associated with other pathogens, namely, plant-parasitic nematodes (PPNs).

PPNs are important pathogens, especially in tropical countries, including Indonesia. The effect of PPNs in decreasing the yield of agricultural commodities in Indonesia is still not realized by farmers, society, or agriculture officials. Nematodes can cause high yield losses and economic damage if not managed properly. Globally, yield losses for agricultural commodities caused by PPNs were estimated at $12.6 \%$ or $\$ 216$ billion per year (Nyaku et al. 2017), while crop damage in Indonesia due to nematode incidence can reach 75\% (Mustika 2005).
PPNs are difficult to identify and control. It is also difficult to show that they are the cause of crop damage. Moreover, damage by PPNs often remains unnoticed as aboveground symptoms are rare and proper diagnosis for nematodes is lacking. PPNs are diverse in their type of parasitism and life cycle. Several major genera of PPNs have been reported in association with maize root systems: Pratylenchus, Helicotylenchus, Xiphinema, Ditylenchus, Meloidogyne, Criconemella, Heterodera, Paratrichodorus, Rotylenchulus, Scutellonema, Longidorus, Radophulus, Trichodorus, Tylenchorhynchus, Globodera, Hemicriconemoides, Haplolaimus, and Scutellonema (CABI 2020). Elhady et al. (2018) reported the Pratylenchus penetrans was an endoparasite that invaded and migrated through roots as a juvenile or adult without becoming sedentary and escaped to the soil when conditions inside roots become adverse. In contrast, they reported that Meloidogyne incognita was a sedentary endoparasite, where the infectious second-stage juveniles entered the root near the tip and established a feeding site near the vascular system. Once done, the juvenile lost its motility and completed its life cycle within the root.

So far, there have been no studies of PPNs diversity in maize cultivation, especially in South Sulawesi. Therefore, the density and diversity of PPNs in the area is an important factor to be studied. This can be used as a preventive measure before PPN incidence results in greater losses. Based on this, it is necessary to conduct research to 
determine the density of living PPNs, their associations with maize plants, and the diversity of PPN species. Additionally, it is necessary to know the diversity of nonparasitic nematodes to help make PPN control decisions. This study aims to analyze PPN density in the vegetative phase of maize in the Malakaji Highland, South Sulawesi.

\section{MATERIALS AND METHODS}

\section{Sample collection}

Sampling was conducted at maize plantations in the Malakaji Highland (5026'17.1" $\mathrm{S}$ and 119050'09.8" E), Gowa Regency, South Sulawesi. The sampling method was a diagonal sampling technique, done by taking samples at points along a diagonal line, which were the middle and fourth corners of the maize crop. Samples were taken in the form of soil in the rhizosphere area of plant roots. To verify the influence of the sampling method on assessments of the nematode communities, based on a modified version by Arieira et al. (2016), stratified sampling was used in collecting soil samples at depths of $0-10 \mathrm{~cm}, 10-20 \mathrm{~cm}$, and $20-30 \mathrm{~cm}$ (total sampling profile depth-30 cm). Samples were stored in separate plastic bags, then stored in a storage box to protect them from direct sunlight. Sampling and observation were carried out every two weeks until the end of the vegetative phase of the crops.

\section{Nematode extraction}

Nematode extraction was done by the modified Baerman method. Twenty-five grams of soil were placed on a small filter lined with filter paper. The filter was placed directly above the container containing the water. The bottom of the filter was lowered to touch the surface of the water until the soil was soaked, then incubated for 48 hours. The collected suspension was then filtered using a 500 mesh sieve and placed in a nematode collection tube. The nematodes in suspension were observed and counted under a stereomicroscope (Mirsam et al. 2015a).

\section{Making non-permanent preparations}

The nematodes were taken using a dripping pinch and transferred to the glass. As much as one drop of $70 \%$ alcohol was added to the nematodes that were placed in the glass. This dilution is useful for turning off nematodes, so they are easier to observe. The glass slide was covered using a cover glass.

\section{Nematode density calculation}

The density of the parasitic nematode community was observed under a stereomicroscope. The entire extraction suspension was poured into a Petri dish with a dividing line, then the nematodes were calculated at $40 \mathrm{x}$ magnification with the help of a hand counter. The absolute density (total density), the density of PPNs, and the density of non-parasitic plant nematodes were calculated. The observed variables were based on Norton's (1978) research, namely:

$$
\begin{aligned}
& \mathrm{ACD}=\frac{\mathrm{n}}{100 \mathrm{ml} \text { soil }} \\
& \mathrm{RCD}=\frac{\mathrm{n}}{\mathrm{N}} \\
& \mathrm{AF}=\frac{\mathrm{s}}{\mathrm{S}} \times 100 \% \\
& \mathrm{RF}=\frac{\mathrm{FA}}{\mathrm{F}} \times 100 \% \\
& \mathrm{D}=\frac{\mathrm{KPA} \times \sqrt{\mathrm{FA}}}{100} \times 100 \%
\end{aligned}
$$

Where: ACD, absolute community density; RCD, relative community density; $\mathrm{AF}$, absolute frequency; $\mathrm{RF}$, relative frequency; $\mathrm{F}$, frequency of all nematodes; $\mathrm{D}$, dominance value; $n$, nematode; N, $\Sigma$ all nematodes; S, $\Sigma$ all samples; and s, $\Sigma$ samples containing nematodes.

\section{Observation of morphological characteristics}

Morphological observations were made by looking at the characteristics of each phase of nematode development. Observations were made using a compound microscope and documented using a camera. Identification was done at the genus level by referring to a nematode identification book (Mai and Lyon 1975), and by matching against pictures.

\section{Data analysis}

Correlation between nematode density and age of maize plants was analyzed using simple regression methods. The results of the regression analysis were then interpreted in a line diagram.

\section{RESULTS AND DISCUSSION}

\section{Abundance of plant parasite nematodes per $25 \mathrm{~g}$ of soil}

The highest PPNs abundance was found at two weeks after planting (WAP) with an average of 30.9 head/25 grams of soil. Observation of PPNs in the vegetative phase showed that the number of PPNs had decreased until 6 WAP experienced a slight increase at 8 WAP or the end of the vegetative phase (Figure 1). The amount of PPNs which tend to fluctuate in this study was the same as those reported by Askary et al. (2018) that the population of some PPNs encountered around the rhizosphere fluctuated gradually in the soil with the passage of time and crop condition phase. Although in Malakaji maize field the population of nematodes fluctuated randomly all through observation of study, close observation reveals that the maximum ascends of population occurred during the early vegetative phase of maize. Harni (2014) reported PPNs populations in the rhizosphere were also influenced by root exudates plants produced that could be attractive to the PPNs. Widyati (2013) also reported that plants produced more root exudates in the early phases of growth. Secondary metabolites such as exudates and lysates released by plants into the rhizosphere provide a source of food and energy for soil microbes, both nematodes, and bacteria. 


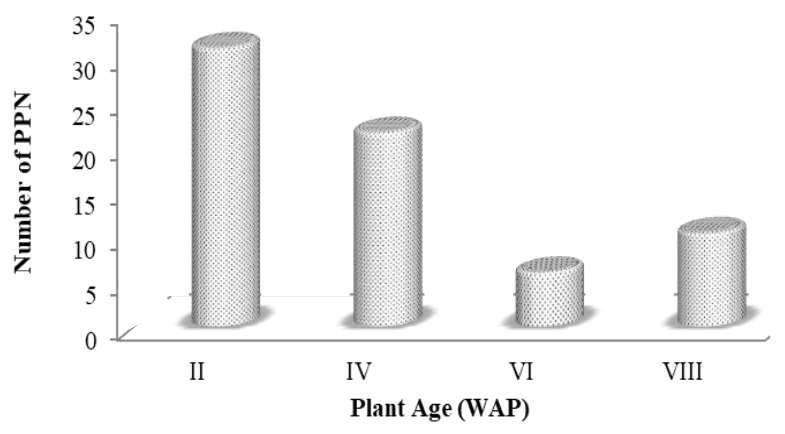

Figure 1. The abundance of PPNs per 25 grams of soil at maize rhizosphere in Malakaji Highland, South Sulawesi

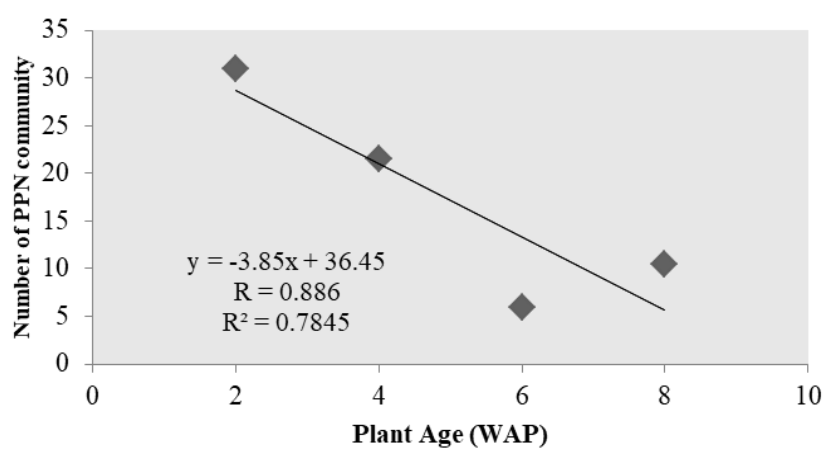

Figure 2. Correlation between plant age and PPNs community at maize rhizosphere in Malakaji Highland, South Sulawesi, Indonesia

Nematode communities generally differ and fluctuate substantially among different locations in terms of abundance, diversity, and occurrence (Franco-Navarro \& Godinez-Vidal 2017). PPNs are usually abundant in the rhizosphere area of plants. The tendency arises because of the presence of plant roots and relatively high oxygen content so that the reproduction rate of nematodes is faster (Agrios 2005). A variety of plant metabolites in roots and exuded from roots to the rhizosphere influence nematode behavior, development, reproduction, and even survival (Dandurand and Knudsen 2016; Wang et al. 2018).

PPNs can migrate through the soil in searching for a host plant where they feed on the liquid content of maize root cells. Damage of root in association with the withdrawal of plant nutrients finally leads to plant damage and yield losses (Nyaku et al., 2017). PPNs cause serious damage and yield losses in a wide range of crops throughout the world estimated to cause $>\$ 80$ billion in losses annually (Nicol et al. 2011). In stressful conditions such as drought, nutrient deficiencies, or other pathogenic incidences, nematodes will increase stress and the plants that attack them can die. In good condition for growth, the host will stay alive, while in a less favorable condition at the same intensity of attack the host will die.

\section{Correlation between plant age and plant parasite nematode community}

The results of the regression analysis showed the value of the correlation/relationship between the age of plants with the PPNs community was 0.886 with a coefficient of determination (R square) of 0.785 so it can be said that the effect of the age of maize on the PPNs community was $78.5 \%$ (Figure 2). Besides, the regression coefficient of (3.85) showed a negative correlation between the age of maize plants and the PPNs community in the rhizosphere region, where the older the age of maize plants, the lower the amount of PPNs. This is presumably because the older the plant, then its ability to produce root exudates also decreases. The root system is one of the biotic factors in the soil that affects the life of PPNs in the rhizosphere. Root exudate produced by plants can stimulate hatching of nematode eggs and also acts as an attractant (attractor) of nematodes to move towards the roots of the host plant.

The population of each nematode species in a longestablished community will fluctuate around the equilibrium. If the population of one organism reaches a high level, then there will be forces that suppress it, and thus for many years, the community remains in its structure. Many species coexist and each is affected by other organisms and non-living environmental factors (abiotic environment). Suyadi and Rosfiansyah (2017) reported population densities of PPNs in the agricultural ecosystem under intensive cultivation were always above the economic injury level. It was justified that PPNs were causal pest which contributing to agricultural ecosystem productivity reduction. The number of PPNs in the field over time will increase and then decrease. The existing population at one time illustrates the results of two opposing tendencies, namely one causes the population to increase, while the other causes the population to decline. The biotic potential of a species is the capacity of the species to reproduce in optimal conditions and conditions without obstacles by its environment.

\section{Plant-parasitic nematode density per $100 \mathrm{ml}$ of soil}

The results of the analysis showed that the highest PPNs density was obtained in 2 weeks old-maize plantations, with a dominance value reaching $61.89 \%$ (Table 1). It was suspected that young plants tend to produce chemical compounds in the form of higher root exudates, where these compounds are known to stimulate the development of PPNs. Also, rainfall at the beginning of planting is high enough to stimulate the growth and development of PPNs. Grabau and Vann (2017) reported the PPNs of maize to spend their entire life in the soil or roots and can be classified by where they reside when feeding.

Table 1. The density of PPNs at maize rhizosphere in Malakaji Highland, South Sulawesi, Indonesia

\begin{tabular}{cccccc}
\hline $\begin{array}{c}\text { Plant age } \\
\text { (WAP) }\end{array}$ & ACD & RCD (\%) & AF (\%) & RF (\%) & $\mathbf{D}(\%)$ \\
\hline 2 & 618 & 44.91 & 100 & 29.07 & 61.80 \\
4 & 430 & 31.25 & 100 & 29.07 & 43.00 \\
6 & 120 & 8.72 & 100 & 29.07 & 12.00 \\
8 & 208 & 15.12 & 100 & 29.07 & 20.80 \\
\hline Note: ACD: & absolute & community & density; & RCD: & relative \\
community density; AF: absolute & frequency; & RF: & relative \\
frequency; D: the value of domination & & &
\end{tabular}


PPNs density in maize plantations in the Malakaji Highland region tends to decrease following the age of the plants that were getting older. The PPNs density represents the number or number of individuals per unit of land unit or host plant network. PPNs density can increase rapidly in a relatively short time due to high reproductive rates, short life cycles, and the availability of suitable food sources. The life cycle of PPNs varies greatly (on average 3-6 weeks can even reach more than one year) during the growing season of plants. In addition, the length (duration) of the life cycle and longevity of PPNs is also influenced by the temperature and humidity of the surrounding soil.

\section{Diversity of nematodes}

Plant-parasitic nematodes

Morphological identification results showed that Five genera of parasite nematodes associated with the rhizosphere of maize plants were found in Malakaji Highland, namely Helicotylenchus, Pratylenchus, Haplolaimus, Longidorus, and Xiphinema. The five PPNs genera found were cosmopolitan or had a broad host range. The diversity of nematodes and abundance of each group of parasitic and non-parasitic nematodes found in maize plantations in the Malakaji Highland can be used as a benchmark for soil quality conditions. According to Kimenju et al. (2009), the PPNs could be interacted with soil organisms in the complexity of food networks.

Helicotylenchus was identified as having a relatively long stylet with stomato stylete type, non-set-off lips, smooth annulation, blunt tail tip, and rather obese body size and resting phase in spiral circular letters (Figure 3). Crow (2017) reported the body of Helicotylenchus spp. formed a complete spiral when the nematode was dead or relaxed. The vulva of the female was located around $2 / 3$ of the nematode's body length from the anterior terminus. The tail was asymmetrical, being curved dorsally with a rounded projection in many species. Helicotylenchus spp. typically feed on cortical cells of host roots. The nematode inserts its mouth spear (stylet) into the epidermis and cortical cells and ingests the cellular contents.

The morphological characters of Pratylenchus were found to be the same as those reported by Mirsam et al. (2015b), the resting phase in the form of the letter $\mathrm{C}$ and rather slender, low head region, flat lips, short-styled, thick, and has a basal knob (stomato stylet), the esophageal glands overlap with the intestine in the ventral section, have relatively smooth annulation, and the tail is long and rather blunt (Figure 4). Pratylenchus also called a rootbearing nematode, is an endoparasitic nematode that attacks and migrates through the roots and then enters plant tissue to infect (Elhady et al. 2018). Previous research showed that Pratylenchus was migratory, feeding mainly in the root cortex and entered vascular tissues obtaining nutrients. Infection typically produced lesion formation and necrosis on roots with aboveground symptoms of chlorosis as well as reductions in leaf number and size (Smiley 2015; Jones and Fosu-Nyarko 2014).

Haplolaimus has a characteristic set-off lip that is equipped with a relatively short and thick stylet with a clear basal knob (stomato stylet), smooth annulation, and a rounded tail tip (Figure 5). According to Holguin et al. (2015), Hoplolaimus spp. feed on the roots of a wide range of plants, some of which are agronomic crops. Morphometric values of amphimictic lance nematode species overlap considerably, and useful morphological characters for their discrimination require high magnification and significant diagnostic time. Damage of Haplolaimus may show up as patches of yellowing, dying, or unthrifty. These symptoms also can be caused by drought or nutrient deficiency. Examination of the roots will reveal thorough damage to the root system.

Longidorus has a morphological character of long body size and is rather slender, a C-shaped body or slightly curled in the resting phase, the front shrinks, the head is continuous or slightly set-off; flat lip and equipped with a long, slim stylet with odonto stylet type (Figure 6). The morphological characters of Longidorus were found to be the same as those of Gharibzadeh et al. (2018) i.e., the body long and narrow, very gradually tapering towards both ends, more so towards the anterior end, open Cshaped after heat relaxation, with posterior body end usually ventrally bent. Cuticle distinctly two-layered with very fine transverse striation mostly visible at the dorsal side of the tail. Stylet type i.e., Odontostyle relatively short, narrow, typical of the genus.

Xiphinema has characteristics such as body size rather fat, lip type rather flat and not set-off and is equipped with a relatively long stylet with odonto stylet type, smooth annulation, and a tapered tail tip (Figure 7). Özturk et al. (2018) explain that body forming an open spiral when killed. Labial region rounded, set off from rest of body by slight depression. Vulva, a transverse slit with slightly prominent lips, located approximately equatorially; vagina occupying $1 / 3$ of corresponding body diameter. Tail conoid, well curved dorsally, with 2-3 caudal pores. Tail tip more or less rounded. Xiphinema of migratory ectoparasitic nematodes which causes root galls in young roots by feeding which results in hypertrophy in cell and necrosis.

According to Bernard et al. (2017), the most successful species of all the important PPNs are the sedentary groups that establish a permanent feeding site within the plant host and obtain nutrients while completing their lifecycles. Sedentary nematodes have a natural advantage over their migratory relatives due to a fascinating and complex method of host cell transformation resulting in the development of a sustainable feeding structure. 


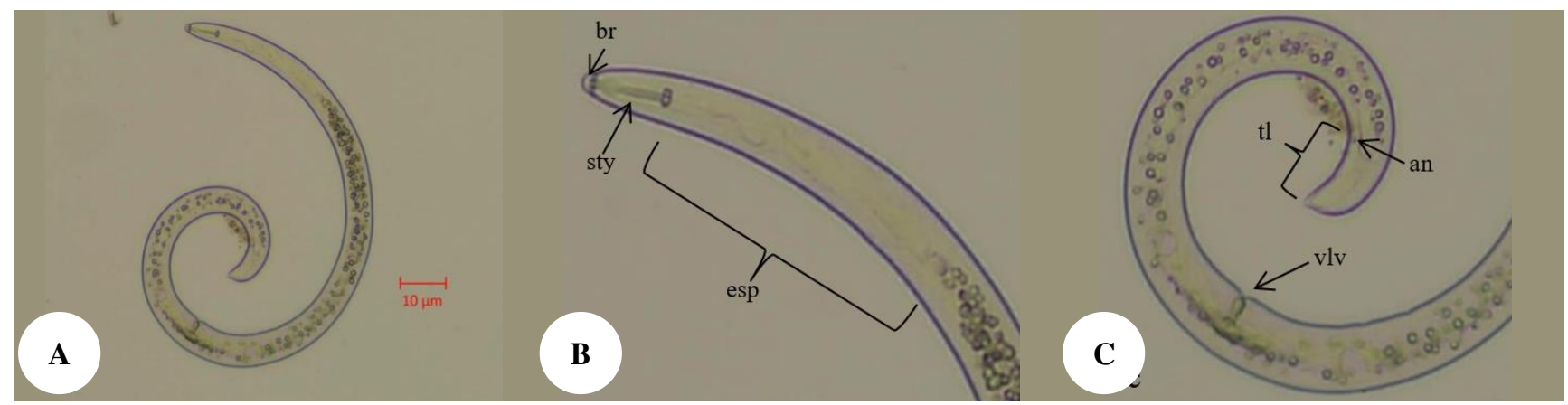

Figure 3. Morphological characters of Helicotylenchus spp. A. Appearance of the whole body B. Anterior body parts C. Posterior body parts. br: lips, sty: stylet, esp: esophagus, tl: tail, anus: anus, vlv: vulva

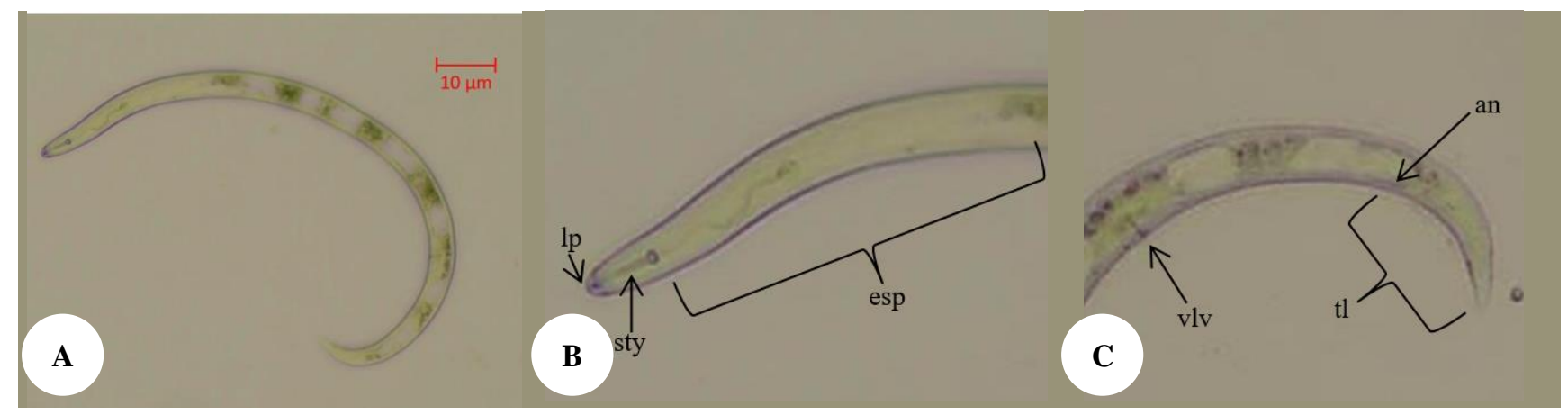

Figure 4. Pratylenchus spp. Morphological characters. A. Appearance of the whole body B. Anterior body parts C. Posterior body parts. lp: lips, sty: stylet, esp: esophagus, tl: tail, an: anus, vlv: vulva

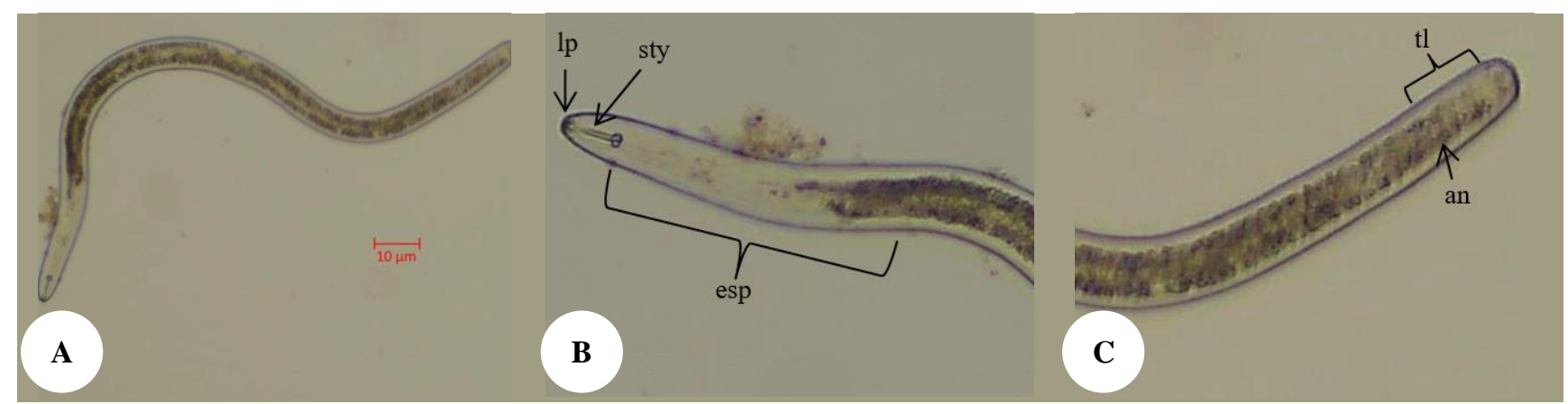

Figure 5. Morphological characters of Haplolaimus spp. A. Appearance of the whole body B. Anterior body parts C. Posterior body parts. lp: lips, sty: stylet, esp: esophagus, tl: tail, an: anus

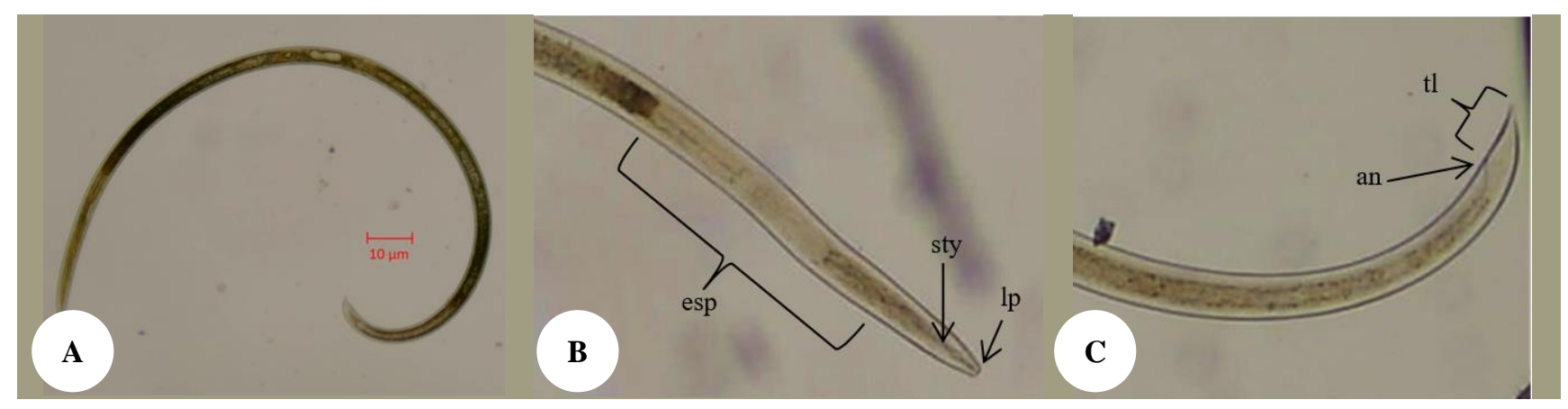

Figure 6. Morphological characters of Longidorus spp. A. Appearance of the whole body B. Anterior body parts C. Posterior body parts. lp: lips, sty: stylet, esp: esophagus, tl: tail, an: anus 


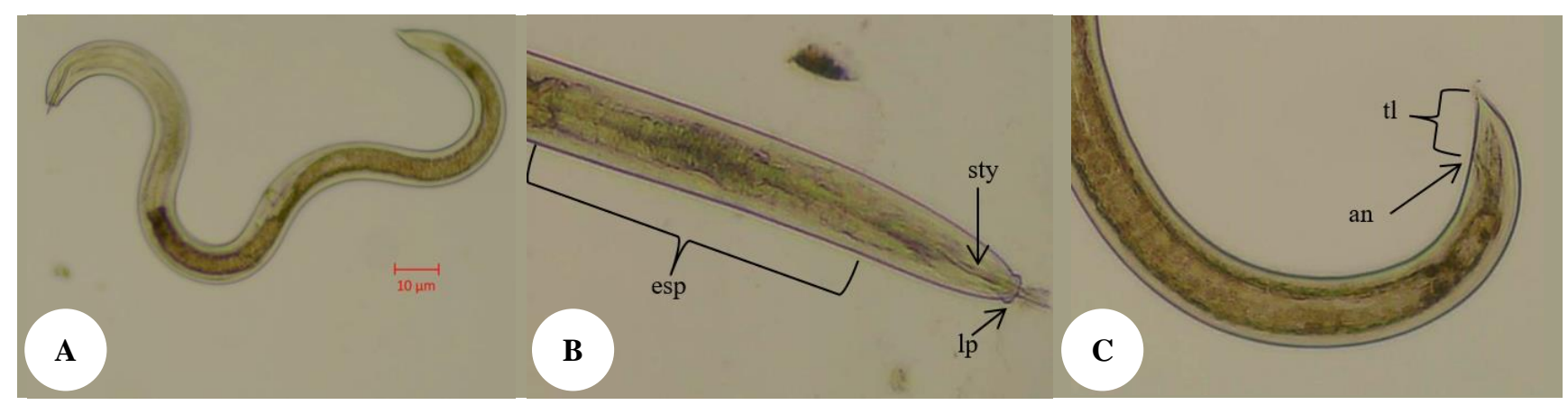

Figure 7. Morphological characters of Xiphinema spp. A. Appearance of the whole body B. Anterior body parts C. Posterior body parts. lp: lips, sty: stylet, esp: esophagus, tl: tail, an: anus

\section{Non-parasitic nematodes}

In addition to parasitic nematodes, three types of nonparasitic nematodes were also found, namely Campydoroides, Mononchus, and Rhabditis. Non-parasitic nematodes are identified as not having a stylet, and are smaller in body size, and in living conditions, these nematodes are more active in motion than parasitic nematodes. Campydoroides nematodes are identified by flat lip features, have stomas with the subglobular type (the open funnel) consisting of dorsal teeth (dorsal tooth), and has a long tail with long elongate-conoid filiform type (Figure 8). Mononchus nematodes have lip features that are flat and slightly bumpy, have stomas of the subglobular type (the open funnel) consisting of dorsal teeth, and have cylindrical and relatively long tails (Figure 9). According to Tahsen and Rajan (2009), Mononchus nematodes have morphological characteristics, namely female nematodes of medium size, in the lip area having a continuous shape with parts of the body. The Cavity bus has a medium size and then continues to grow. Dorsal teeth are in $25-30 \%$ of the anterior buccal cavity. This nematode has a long cylindrical tail shape and the male nematode does not. Rhabditis nematodes have morphological characteristics as follows: they do not have stylet or teeth, the lips tend to be flat, have stoma with the cylindrical type (funnel-like channels) consisting of cheilostom, gymnostom, and stegostom. The metacarpus is enlarged and the tail is smaller and tends to be tapered and blunt to the tip. Widowati et al. (2014) and Panahandeh et al. (2018) explained that the genus Rhabditis, which has the characteristics of not having setae or sometimes not clear, stoma walls are tubular, do not have stylet or teeth, the esophagus is well developed, and the metacorpus part is enlarged.

The morphology of non-parasitic nematodes is almost the same as the morphology of parasitic nematodes. The main difference between the two lies in the shape and structure of the mouth instrument. The mouthpiece on a non-parasitic nematode is shaped like a funnel that is wide open and has no stylet. Stoma is one of the characteristics that can be used in determining the nature of the nematode. Stoma is the anteriormost part of the nematode digestive tract. The shape and size of the stoma in each type of nematode is different depending on the nature of the prey. Nematodes that are bacterial and fungal eaters generally have stomas that form tubes or funnels, such as those of the genus Rhabditis (Figure 10). Whereas predatory nematodes have a thrust-shaped stoma that is more wide open and not equipped with teeth (Figures 8 and 9). Non-parasitic nematodes live mostly as predators of fungi and pathogenic bacteria and entomopathogens. The group's nematodes play an important role in the food chain and as biological agents. Nematodes play a crucial role in important ecosystem services such as nutrient recycling and decomposition, suppression of pathogenic microorganisms, and biodegradation of harmful compounds. As a result, changes in nematode community composition (assemblage) may have a substantial impact on ecosystem functioning (Wada et al. 2011; Fraschetti et al. 2016).

Nematodes are the most abundant and diverse metazoan present in all types of soils. Based on feeding types, they are microphagous, saprophagous, phytophagous, and predaceous. All these types of nematodes occur in soil concomitantly. Non-parasitic nematodes of free-living plants are very important and useful in the decomposition of organic matter and the recycling of nutrients in the soil. The predaceous nematodes play a significant role in regulating the population of PPNs. Based on the type of feeding apparatus and mode of feeding, predatory nematode is classified into different taxonomic categories (Devi and George 2018). In addition, there are also nematodes bacterivores and fungivores do not feed directly on soil organic matter, but on bacteria and fungi that function as decomposers. The presence and eating process of these nematodes accelerates the decomposition and mineralization process. 


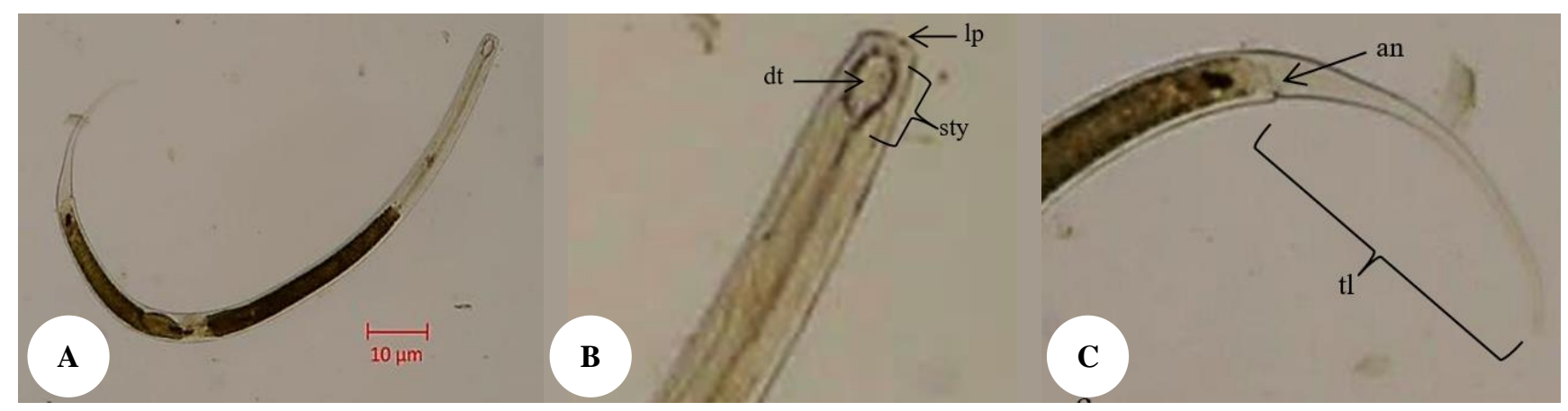

Figure 8. Morphological characters of the genus Campydoroides (predators). A. Appearance of the whole body; B. Anterior body parts; C. Posterior body parts. lp: lips, st: stoma/ buccal capsul, dt: dorsal tooth, tl: tail, an: anus

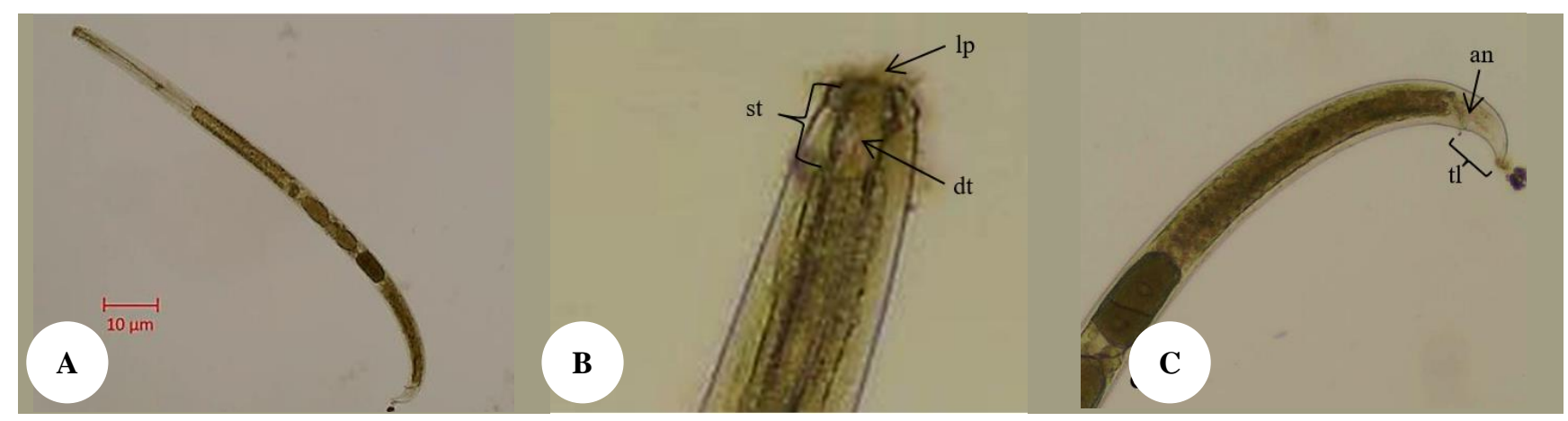

Figure 9. Morphological characters of the genus Mononchus (predator). A. Appearance of the whole body, B. Anterior body parts; C. Posterior body parts. lp: lips, st: stoma/ buccal capsul, dt: dorsal tooth, tl: tail, an: anus.

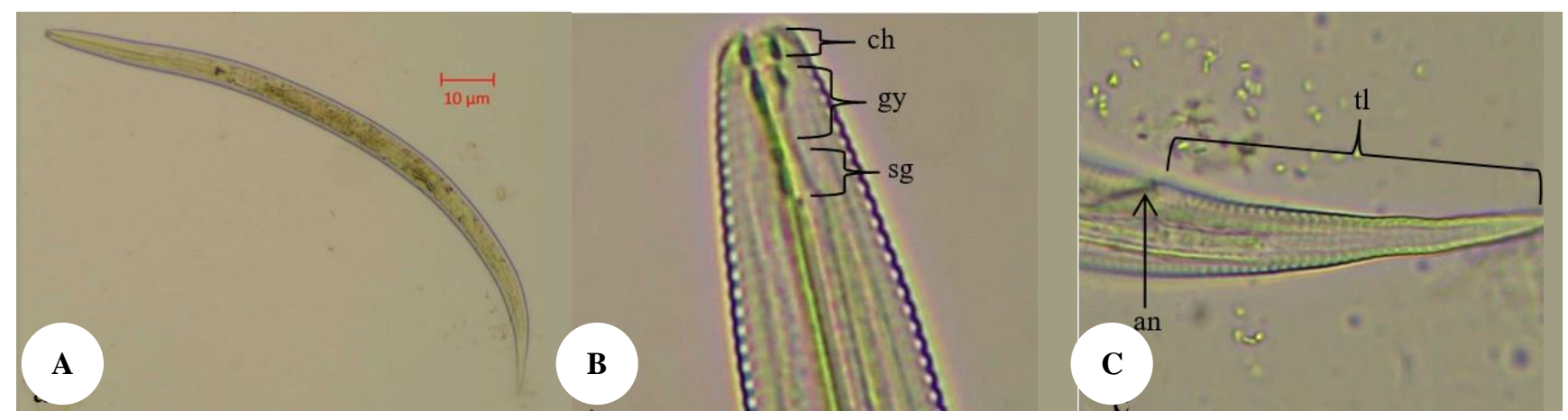

Figure 10. Morphological characters of the genus Rhabditis (bacterial and fungal feeder). A. Appearance of the whole body, B. Anterior body parts, C. Posterior body parts. lp: lips, st: stoma/ buccal capsul, dt: dorsal tooth, tl: tail, an: anus

In conclusion, the highest PPNs density was found in maize plants at 2 weeks after planting with an absolute community density reaching 618 and a dominance value of $61.80 \%$. Age of maize plants is negatively correlated with PPNs community with a regression coefficient of (-3.85) so that it can be assumed that the older the age of maize plants, the lower the amount of PPN. Five genera of plantparasitic nematodes associated with the rhizosphere of maize plants, namely Helicotylenchus, Pratylenchus, Haplolaimus, Longidorus, and Xiphinema. In addition to parasitic nematodes, three genera of non-parasitic nematodes were also found, namely Campydoroides, Mononchus, and Rhabditis. This data can be used as a preventive measure before PPN incidence results in greater losses on maize.

\section{ACKNOWLEDGEMENTS}

The author would like to thank the Indonesian Cereals Research Institute, Indonesian Center for Food Crops Research and Development, Indonesian Agency for 
Agricultural Research and Development, Ministry of Agriculture for supporting and contributing to this research. We also expand our thanks to Hasbi of the Indonesian Cereals Research Institute for helping in collecting samples from the field.

\section{REFERENCES}

Agrios G. 2005. Plant Pathology 5th Edition. Academic Press, San Diego. Arieira GO, Santiago DC, Franchini JC, and Guimarães MF. 2016. Depthstratified soil sampling for assessing nematode communities. Semina Ciencias Agrarias 37 (2): 715-728.

Askary TH, Khalil A, Khan AA, Nazir N. 2018. Population fluctuation of plant-parasitic nematodes associated with grapevine under hi-tech and low-tech polyhouse conditions. Intl J Current Microbiol Appl Sci 7 (5): 2133-2140.

Bernard, Gregory C, Egnin M, Bonsi C. 2017. The Impact of PlantParasitic Nematodes on Agriculture and Methods of Control. In Shah MM, Mahamood M (eds) Nematology-Concepts, Diagnosis and Control. InTech, Croatia.

CABI. 2020. Crop Protection Compendium. CAB International, Wallingford, UK.

CBS [Central Bureau of Statistics]. 2018. Harvested Area, Production, and Productivity of Corn and Soybean in South Sulawesi Province. Central Statistics Agency of South Sulawesi, Makassar.

Crow WT. 2017. Spiral Nematode Helicotylenchus spp. (Nematoda: Tylenchida: Hoplolaimidae). IFAS Ext, Univ Florida, Miami, FL.

Dandurand LM, Knudsen GR. 2016. Effect of the trap crop Solanum sisymbriifolium and two biocontrol fungi on reproduction of the potato cyst nematode, Globodera pallida. Ann Appl Biol 169 (2): 180-189.

Devi G, George J. 2018. Predatory nematodes as bio-control agents against plant-parasitic nematode-A review. Agric Res Commun Centre J 39 (1): 55-61

Elhady A, Adss S, Hallman J, Heuer H. 2018. Rhizosphere microbiomes modulated by pre-crops assisted plants in defense against plantparasitic nematodes. Front Microbiol 9: 1-9.

Franco-Navarro F, Godinez-Vidal D. 2017. Soil nematodes associated with different land uses in the Los Tuxtlas Biosphere Reserve, Veracruz, Mexico. Revista Mexicana de Biodiversidad 88: 136-145.

Fraschetti S, Guarnieri G, Bevilacqua S, Terlizz A, Danovaro R. 2016. Impact of offshore gas platforms on the structural and biodiversity of nematodes. Marine Environ Res 111: 56-64.

Gharibzadeh F, Pourjam E, Pedram M. 2018. Description of Longidorus azarbaijanensis n. sp. (Dorylaimida: Longidoridae) from Iran. J Nematol 50: 1-12

Grabau ZJ, Vann C. 2017. Management of Plant-Parasitic Nematodes in Florida Field Corn Production. IFAS Ext, Univ Florida, Miami, FL.

Harni R. 2014. Plant resistance to parasitic nematodes. Sirinov 2 (3): 171178

Holguin, Claudia M, Baeza JA, Mueller JD, Agudelo P. 2015. High genetic diversity and geographic subdivision of three lance nematode species (Hoplolaimus spp.) in the United States. Ecol Evol 5 (14): 2929-2944.

Jones MGK, Fosu-Nyarko J. 2014. Molecular biology of root lesion nematodes (Pratylenchus spp.) and their interaction with host plants. Annals Appl Biol 164: 163-181.
Kimenju KW, Karanja NK, Mutua GK, Rimberia BM, Wachra PM. 2009. Nematode community structure as influence by land use and intensity cultivation. Trop Subtrop Agroecosyst 11: 353-360.

Mai WF, Lyon HH. 1975. Pictorial key to genera of plant-parasitic nematodes. Cornell University Press, Ithaca.

Mirsam H, Supramana S, Suastika G. 2015b. Identifikasi nematoda parasit pada tanaman wortel di dataran tinggi malino, sulawesi selatan berdasarkan pada ciri morfologi dan morfometrik. Jurnal Fitopatologi Indonesia 11 (3): 85. [Indonesian]

Mirsam H, Supramana S, Suastika G. 2015a. Deteksi dan identifikasi spesies Meloidogyne pada tanaman wortel dari Dataran Tinggi Malino, Gowa, Sulawesi Selatan. Jurnal Fitopatologi Indonesia 11 (1): 1-8. [Indonesian]

Mustika I. 2015. Konsepsi dan strategi pengendalian nematoda parasit tanaman perkebunan di Indonesia. Perspektif 4 (1): 20-32.

Nicol JM, Turner SJ, Coyne DL, Nijs Ld, Hockland S, Maafi ZT. 2011. Current nematode threats to world agriculture. In: John J, Godelieve G, Carmen F. (eds.) Genomics and Molecular Genetics of PlantNematode Interactions. Springer, Dordrecht.

Norton DC. 1979. Ecology of Plant-Parasitic Nematodes. John Wiley, Toronto.

Nyaku ST, Affokpon A, Danquah A, Brentu FC. 2017. Harnessing useful rhizosphere microorganisms for nematode control. In: Shah MM, Mahamood M (eds.). Nematology - Concepts, Diagnosis and Control. In Tech, London.

Özturk L, Behmand T, Sin B, Avci GG, Elekcioğlu IH. 2018. Morphologic and molecular identification of Xiphinema americanum associated with pine trees. Int J Mol Biol 3 (3): 94-96.

Panahandeh Y, Abolafia J, Pourjam E., Giblin-Davis RM, Afshar FJ, Pedram M. 2018. Morphological and molecular characterization of Labrys filiformis n. sp. (Rhabditida: Tylenchidae) from Iran. J Nematol 50: 343-354.

Smiley RW. 2015. Root-lesion nematodes: biology and management in pacific northwest wheat cropping systems. A Pacific Northwest Extension Publication 617: 1-14.

Soenartiningsih, Akil M, Andayani NN. 2015. Soil-borne fungus (Rhizoctonia solani) the pathogen of sheath blight disease of maize and sorghum and its control measure. IPTEK Tanaman Pangan 10: 85-91. [Indonesian]

Suriani, Muis A. 2016. Prospect of Bacillus subtilis as a biological control agent of soilborne pathogens on maize. Jurnal Penelitian dan Pengembangan Pertanian 35: 37-45. [Indonesian]

Suyadi, Rosfiansyah. 2017. The role of plant-parasitic nematodes on productivity reduction of banana and tomato in East Kalimantan, Indonesia. Asian J Agricult 1 (1): 40-45.

Tahsen Q, Rajan P. 2009. Description of Mononchus intermedius. Nematologia Mediterranea 37: 161-167.

Wada S, Toyota K, Takada A. 2011. Effects of nematicide imicyafos on soil nematode community structure and damage of radish caused by Pratylenchus penetrans. J Nematol 43: 1-6

Wang C, Masler EP, Rogers ST. 2018. Responses of Heterodera glycines and Meloidogyne incognita infective juveniles to root tissues, root exudates, and root extracts from three plant species. Plant Disease 102 (9): $1733-1740$

Widyati E. 2013. Rhizosphere microbes community dynamic and it contributes to plant growth. Tekno Hutan Tanaman 6 (2): 55-64. [Indonesian] 